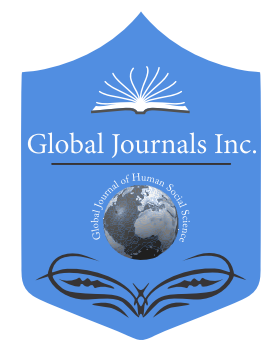

\title{
Brazilian Military History: Perspectives on History Writing
}

By Fabio da Silva Pereira

Universidade Salgado de Oliveira

Abstract- The article aims to present historiographical perspectives for Military History theory. For this, the researchers had access to specialized bibliography to contextualize classics of the three strands, analyzing how history is written from the 19th century to contemporary times. The Traditional, Marxist, and New History currents, concomitant with examples described in works in Military History, received decisive contributions to professional improvement in scientific activity throughout this period. In this way, it provides young researchers with the opportunity to innovate and find new information to deepen the historical knowledge of Military History issues: leaders, institutions, mentality, and values.

Keywords: brazilian historiography, theory of history, brazilian military history, history writing.

GJHSS-D Classification: FOR Code: 430299

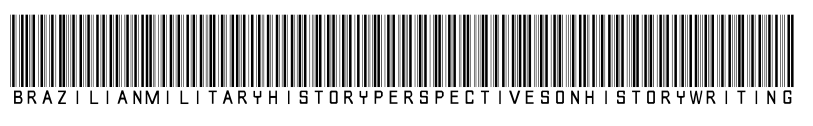

Strictly as per the compliance and regulations of:

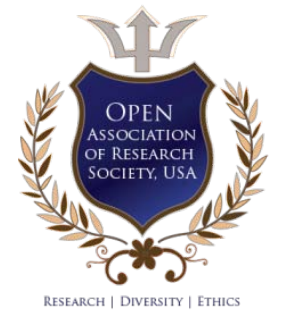

(C) 2021. Fabio da Silva Pereira. This is a research/review paper, distributed under the terms of the Creative Commons AttributionNoncommercial 3.0 Unported License http://creativecommons.org/licenses/by-nc/3.0/), permitting all non-commercial use, distribution, and reproduction in any medium, provided the original work is properly cited. 


\title{
Brazilian Military History: Perspectives on History Writing
}

\author{
Fabio da Silva Pereira
}

Abstract ${ }^{1}$ - The article aims to present historiographical perspectives for Military History theory. For this, the researchers had access to specialized bibliography to contextualize classics of the three strands, analyzing how history is written from the 19th century to contemporary times. The Traditional, Marxist, and New History currents, concomitant with examples described in works in Military History, received decisive contributions to professional improvement in scientific activity throughout this period. In this way, it provides young researchers with the opportunity to innovate and find new information to deepen the historical knowledge of Military History issues: leaders, institutions, mentality, and values.

Keywords: brazilian historiography, theory of history, brazilian military history, history writing.

\section{InTRODUCTION}

T he narrative from different angles calls attention to a closer look based on observing the phenomena that involve people in time. Therefore, the present study intends to elucidate the transformations of contemporary historiography in the face of the military theme. Synthetically, historiography passed through three periods of great relevance: the first stage corresponded to the historical perception of Leopold von Ranke. Leopold von Ranke (1795 - 1886) is considered one of the forerunners of scientific history in the nineteenth century. He stood out for spreading the importance of the wide use of documentary sources, including "memoirs, diaries, personal and formal letters, government letters, diplomatic pouches and texts, and first-hand testimonies from eyewitnesses for argumentative composition; and by trying to narrate history as it occurred. He focused basically in the writing of history centered on facts, places, and leaders. Thus,

Author: Ph.D. Student Researcher at Salgado de Oliveira University (UNIVERSO). Member of the Scientific Committee of the Military History Working Group of the National History Association, Rio de Janeiro section (Anpuh - RJ). Professor of Military History, approved for Specific Functional Qualification Teaching (QFE) at Academia Militar das Agulhas Negras (AMAN). Tutor of Brazilian History at the Federal University of the State of Rio de Janeiro (UNIRIO). Degree in History at the Federal University of the State of Rio de Janeiro (UNIRIO), Master in Military Operations at Escola de Aperfeiçoamento de Oficiais(EsAO), Master in Public Administration at Fundação Getúlio Vargas (FGV), Master in Military Education at Centro de Estudos de Pessoal e Forte Duque de Caxias(CEP/FDC). e-mail: fabio.pereira.historia@gmail.com

${ }^{1}$ Academicadvisor: Dr. Fernando da Silva RODRIGUES (UNIVERSO) My special thanks to Professor M. Ed. Arlindo José de BARROS JUNIOR (AMAN), who kindly reviewed this study. it is possible to understand that currently, what we call "history is seen from above" shows the acts of great leaders and the battles and consequences of the action for transformations that are more focused on politics than on society.

The second stage began at the dawn of the 1900s, with impacts from that reflection years later, especially in France. The creation of Annales d'historie économique et sociale. The dissatisfaction that the young historian's Marc Bloch and Lucien Febvre showed, in the 1910s and 1920s, about to link political history to the relative poverty of their analyses, reducing complex historical situations to a simple power game between large ones - men or countries - ignoring that, below and beyond it, there were structural, collective and individual fields of forces that gave it density and depth incompatible with what seemed to be the frivolity of events. Bloch and Febvre founded the Annales magazine, in addition to producing significant personal work, to make it an instrument for enriching history, for its approximation with neighboring sciences, and the encouragement of thematic innovation (Burke, 1991). They sought to highlight, in a different way, the "history seen from below," with the contributions of soldiers who experienced conflicts and changes in the institutional landscape over time, shifting the focus to more social history, with a reduced scope among the categories to be analyzed. Furthermore, the observation of the points that generated some tension between these same classes was still under the vision of this generation of historians who prevailed in the scientific scene until the end of the 1970s.

The third and last historiographic current, the nouvelle histoire - the new history in French, also brought new approaches. It is possible to observe the methodological resource of oral history, the growing appreciation of biographies, the interdisciplinary, and the expansion of documents to be consulted beyond the political and institutional perspective. As a result, an infinity of research on the military theme appears on a scale never seen before, having as a political consequence the recent creation of Thematic Groups of Military History in the National Association of History ${ }^{2}$ (Anpuh), in Brazil.

2 The Military History Working Group of the National History Association, Rio de Janeiro section (Anpuh/RJ), created in 2016, aims to bring together professionals in the area of Human Sciences and Social Sciences dedicated to research and teaching in its various 
To facilitate the achievement of the research this, specific objectives were presented, whose organization is based on the contextualization and observation of some transformations that characterize the rupture of paradigms in the craft of writing history. To achieve this goal, searches for documents were carried out as well as a study of the structured bibliography by specialists on the subject.

Regarding the methodology, the base of the present work is on the contributions of Barros (2013), Cardoso and Vainfas (2012), according to the following classifications: regarding the type (or objective), it is descriptive research, and, about the methodological procedures, it consists of a bibliographic and documental analysis.

\section{Literature ReVieW}

The transformations in history writing concern what has happened between historians and other academic researchers in the past. They include surveys and critical assessments of various trends in history, as well as interventions in debates. The Historian Eric Hobsbawm vigorously defends the view that what historians investigate is real (Hobsbawm, 2013). The point at which historians must start, no matter how far they may go, is fundamental and, for him, the absolutely central distinction between verifiable fact and fiction, between evidence-based historical statements which are subject to disclosure and those that are not. The new history is history written as a deliberate reaction against the traditional "paradigm," a term put into circulation by the American science historian Thomas Kuhn.

Physicist Thomas Kuhn (1922 - 1996) demonstrated that sciences are not only human constructions but also, and consequently, social and historical constructions. This results in a new understanding of scientific processes and, thus, of scientific literacy. Kuhn presented the following definition of paradigm: "I consider 'paradigms' to be universally recognized scientific achievements that, for a time, provide model problems and solutions for a community of practitioners of a science" (Kuhn, 1997). These tasks of the historian, however, are complex and refer to different understandings of what science is. Kuhn argues that: "Perhaps science does not develop by accumulating individual discoveries and inventions" (Kuhn, 1997). Thus, when historians dedicate themselves to the study of a scientific conception or theory, they realize that, at that time, they were as

approaches, including researchers from different civil and military backgrounds, interested in presenting and discussing their research work. In this sense, the social function of the consortium formed by military institutions and higher education institutions stands out for the establishment of exchanges with qualified researchers and contact with recent national and international historiographic production (ANPUH/RJ, 2021). scientific as the theories we have today. Contrary to what we have always seen in scientific manuals, science is not the gradual accumulation of knowledge but the complex relationship between theories, data, and paradigms (Bartelmebs, 2012). It will be interesting to point this traditional paradigm as "Ranke's history" after the great German Historian Leopold von Ranke, although this was less limited by him than his followers (Burke, 2011).

\section{a) Traditional History}

The past we study is just a construct of our minds (Hobsbawm, 2013). In principle, this is as valid as the other, whether or not it is supported by logic and evidence. Professor Francisco Falcon ${ }^{3}$, in one of his classes on the theory of history, emphasized the historian's commitment to the truth, but this does not become absolute: it is a responsibility that the history professional assumes when analyzing the sources they have. Any narrative without scientific proof runs the risk of becoming a fictional work, that is, a non-history one.

The superficial logic and common sense bring the idea that there are no arguments against facts; however, the appearance of new methodologies broadens the debate about them. In this aspect, the event is the investigative starting point for the historian through the interpretation of the chosen samples about a phenomenon. The historians must remember their responsibility, which is, above all, to exempt themselves from the passions of political identity. The past is, therefore, a permanent dimension of human consciousness, an inevitable component of society's institutions, values, and other standards. The problem for historians is to analyze the meaning nature of the past in society and locate its changes and transformations in the exercise of historicity between the present and the past (Hobsbawm, 2013).

Total domination of the past could exclude all legitimate changes and innovations. It is unlikely that there is any society that does not recognize any of them. Innovation can happen in a form to officially to define the past. It must be a special selection from the infinity of what can be remembered. In this situation, the perception of conflicts is certainly enhanced by

\footnotetext{
${ }^{3}$ Born on March 30, 1933, Francisco José Calazans Falcon was a professor at the former National Faculty of Philosophy (FNFi), at the Fluminense Federal University (UFF), at the Pontifical Catholic University of Rio de Janeiro (PUC) and is currently a professor of the Post-Graduate Program at Universidade Salgado de Oliveira (UNIVERSO). In addition, he participated in the Committees of the National Council for Scientific and Technological Development (CNPq), the Coordination for the Improvement of Higher Education Personnel (CAPES), and the Board of Directors of the Carlos Chagas Filho Foundation for Research Support of the State of Rio de Janeiro (FAPERJ). A scholar, he has published several books in the fields of historiography, Brazilian history, contemporary history, and modern history (Café História, 2017). Class taught in Theory of History at Salgado de Oliveira University in the second half of 2018.
} 
presenting opposing points of view than by attempting to articulate a consensus. This perspective caused a shift from the ideal of the current of history to that of heteroglossia, defined as varied and opposing voices (Burke, 2011). Thus, there is a concern about the scope of human activity that encourages historians to search for other disciplines, such as sociology, economics, political science, statistics, linguistics, psychology, and literature.

The formalized social past is more rigid, as it sets the standard for the present. The belief that the present must reproduce the past implies a positively slow pace of historical change; otherwise, it would not be and would not appear realistic. As long as the change has been gradual enough to be absorbed, it can be permeated into the formalized social past in the form of a used, and perhaps, ritualized mythological story, by a tacit modification of the belief system, by the stretching of the normative framework, or in other ways (Hobsbawm, 2013).

The belief that traditional society is static immutable is a myth of vulgar social science. Nevertheless, to some extent, change may remain traditional: a bucket from the past continues to shape the present, or so one can imagine. When social change accelerates and transforms society beyond a certain point, the past must cease to be the pattern. The event appears as one of the characteristics of traditional historiography. Historian Peter Burke has summarized the paradigm in the following table:

Tab. 1: Perspectives of traditional historiography according to Burke (2011). Adaptation made by the author.

\begin{tabular}{|c|c|c|}
\hline & $\begin{array}{l}\text { Alignment with ancient } \\
\text { political history }\end{array}$ & $\begin{array}{l}\text { According to the traditional paradigm, history is essentially about politics. In the bold } \\
\text { Victorian phrase of Cambridge professor of history Saron Sirlei, "history is past } \\
\text { politics, politics is present history." Politics was admitted to be essentially state- } \\
\text { related. And, in other words, it was more national and international than regional. } \\
\text { However, it does not include what the military theorist Karl von Clausewitz defines as } \\
\text { the continuation of politics by other means, namely, war. While other types of history } \\
\text { were not entirely excluded by the traditional paradigm, they were marginalized in the } \\
\text { sense that they were considered peripheral to the interests of true historians. }\end{array}$ \\
\hline & $\begin{array}{l}\text { Traditional historians } \\
\text { think of history as } \\
\text { essentially a narrative of } \\
\text { events }\end{array}$ & $\begin{array}{l}\text { The histoire événementielle, or history of events, according to Fernand Braudel, } \\
\text { represents nothing but than the foam on the waves of the sea of history. What really } \\
\text { matters to this classic author are long-term economic and social changes (la longue } \\
\text { durée) and very long-term geo-historical changes. }\end{array}$ \\
\hline & $\begin{array}{l}\text { Traditional history offers } \\
\text { a "view from above" }\end{array}$ & $\begin{array}{l}\text { The traditional researcher point of view is that he has always focused on the great } \\
\text { deeds of great men, statesmen, generals, or occasionally ecclesiastics. The rest of } \\
\text { humanity was assigned a secondary role in the drama of history. The existence of } \\
\text { this rule is revealed by reactions to its transgression. When Russian writer Alexander } \\
\text { Pushkin was working on an account of a peasant revolt and its leader Pugachev, } \\
\text { Russian Czar Nicholas Il's stated that "such a man has no history." }\end{array}$ \\
\hline 4. & $\begin{array}{l}\text { History should be based } \\
\text { on official documents }\end{array}$ & $\begin{array}{l}\text { One of Leopold von Ranke's great contributions to traditional historiography was his } \\
\text { exposition of the limitations of narrative sources and his emphasis on the need to } \\
\text { base written history on official records, emanating from the government and } \\
\text { preserved in archives. The price of this contribution was the neglect of other kinds of } \\
\text { evidence. Official records generally express the official point of view and to } \\
\text { reconstruct the attitudes of other agents in history, records need to be } \\
\text { supplemented by other types of sources. }\end{array}$ \\
\hline & The History is objective & $\begin{array}{l}\text { The historian's task is to present readers with the facts, or, as Ranke put it in an oft- } \\
\text { quoted sentence, to say "how they actually happened." His modest rejection of } \\
\text { philosophical intentions was interpreted by posterity as a presumptuous manifesto } \\
\text { of history without vicious tendencies. Nowadays, it is generally considered } \\
\text { unrealistic. As hard as we struggle to avoid prejudices associated with color, creed, } \\
\text { class or gender, we cannot help but look at the past from a particular point of view. }\end{array}$ \\
\hline
\end{tabular}

Ranke's historiography, according to Hobsbawm, concentrated all its efforts on the task of establishing the facts and, in doing so, contributed very little to history, except for a set of criteria published in journals that are used to assess certain types of documentary evidence (Hobsbawm, 2013).

In the meantime, it is possible to verify that these documents and procedures only applied to a limited class of historical phenomena because they critically classified certain phenomena as worthy of study, while others did not. Such "choice" of the most important events, from the perspective of the facts ",as they happened," revealed, consciously or unconsciously, the phenomenon of erasing history. The role of history can be understood as a projection from the economy drives to the level of intellectual work of this double task that consists of remembering and forgetting (Ricoeur, 1996). Or even Tzvetan Todorov in his essay "The Abuses of Memory: Memory is not opposed to forgetting." The two contrasting terms figure as the erasure (forgetting) and conservation; memory is, always and necessarily, an interaction between the two 
(Todorov, 1995). For reflection, Peter Burke warned of the creation of stereotypes and the lack of searching for new information based on the fact itself: "Should a military history from below deal with the common soldier, as John Keegan so memorably did (Keegan, 1995), or should it focus on the civilian experience of war?" (Burke, 2011).

But not everything was Philosophy because, as they say, "no one lives on breeze." In addition to Philosophy, Greek thought expanded into other areas, such as the invention of various literary genres, among which History stands out, inaugurated by Herodotus, already in Antiquity known as the "Father of History." History is a Greek word meaning "research" and therefore encompassed several areas of research. However, it soon came to mean "study of the past," and Herodotus inaugurated this genre with a monumental work that dealt with the origins of the wars between the Greeks and the Persians. He visited numerous places, such as Egypt, having coined the famous description of this place as a "gift of the Nile" (Funari, 2020).

Thus, it was unwilling to concentrate on the history of events. In fact, in some countries, it had a clear institutional bias, but the methodology was immediately suitable for chronological narrative. Contextualizing, one can analyze the integrative project of the Brazilian Geographical Historical Institute (IHGB) ${ }^{4}$, which contributed, pari passu, to promote facts and events that redesigned the military history of Brazilian colonization, so that there was predestination for the continuity of command under the Portuguese lineage since the arrival of Pedro Álvares Cabral's expedition in these lands, on April 22nd, 1500. A curious fact is that, among other events surrounding this example, it illustrates that the real motivation for the trip was the trade market in the Indies ${ }^{5}$ and also, that the first territorial landmark in the current Brazilian territory was

\footnotetext{
${ }^{4}$ An institutional space dedicated to History would be achieved through the foundation of the IHGB in 1838. The moment would not be for less. Some of the imperial institutions, such as Pedro II School and the Imperial Public Archive, were not only created in the same period as the IHGB but also participated in the same comprehensive project of forging the Nation, whether in the creation of a national past or in guaranteeing its future, through the formation of those who would be the citizens of the Empire. As noted by Arno Wehling, these institutions should contribute to consolidating education, culture, and public administration in the country; this framework in vain with the moment of consolidation of liberal institutions, which also occurred in Guizot, France (KODAMA, 2013).

5 Pedro Álvares Cabral's expedition did not receive orders from Portuguese King Manuel I to head west. However, the route established provided for a diversion of the current that bathes the southwest of Africa, a fact that prevented the crossing of Boa Esperança Cape (Cape L' Agulhas, near to Cape Town), located in the extreme south from Africa (Portugal, 1940). As a result of the advance towards the west, the sea current initiated in the Azores Archipelago pushed Cabral's expedition to the Bahian coast. The Letter from Pero Vaz de Caminha, a member of the Society of Jesus in that undertaking, documented lands to the west. However, part of the fleet continued its journey towards the Indies, and the other part returned to Portugal to communicate to the king about the event in April 1500.
}

placed by expedition led by Gaspar de Lemos in 1501 in the region of Touros ${ }^{6}$, a municipality in the State of Rio Grande do Norte (RN). It is important to highlight that the purpose of this point is not to question the date of the discovery of Brazil but to present the fact that Lemos' military expedition dedicated to the recognition and territorial constitution of the Portuguese America.

There is no doubt that the discovery and the first document formulated regarding the identification of the new lands - the Letter by Pero Vaz de Caminha (Portugal 1940) - was the central structure of the events that interested to the traditional historian. In short, they represented history in the singular, with facts chosen to condition the linear and "progressive" narrative, thus enunciating a purpose. However, countless events can tell the history under the most different perspectives. In this respect, philosophically and methodologically, traditional academic historians tended to display an equally admirable innocence. It is true that innocence coincided with what, in the natural sciences, was a conscious, albeit controversial, methodology. And what we can roughly call that "positivism," although it is doubtful that many academic historians knew that they were activists of that movement.

In most cases, they were men who accepted a given theme as well as and a given geographic area as the most important. We have another example regarding geographic choice: the centralized narrative of the formation of Brazil based on the importance of the Court installed in Rio de Janeiro, all at the expense of regional history. Evaldo Cabral de Melo Neto harshly criticizes the process of disintegration of the State of Pernambuco during the emancipatory conflicts that took place between 1817 and $1824^{7}$. Another controversial fact was the process of territorial pacification portrayed by José Honório Rodrigues as a bloody fact in a bloodless revolution of territorial integration after independence in 1822 (Rodrigues, 1982). It offers new perspectives on the historical process of territorial unity, as if Brazil were "predestined" to be a country of continental dimensions from the beginning, like the narrative that the IHGB sought to develop.

They also accepted the idea of popularized scientific thought, among others, that, for example, hypotheses that automatically generate from the pathological study, conscious explanation of a set of

\footnotetext{
${ }^{6}$ For preservation reasons, a replica was placed near the Calcanhar Lighthouse in the municipality of Touros. The original monument, made of marble, is located in Forte dos Reis Magos, located in Natal, capital.

${ }^{7}$ As of 1817 , the State of Pernambuco lost more than fifty percent of its territory. As a result of the defeat by the troops of the Court, the Comarca of Alagoas emancipated of that province. In addition, the western and southern portion from Petrolina, corresponding to the Comarca of São Francisco, became a territory of the Province of Bahia.
} 
chains of cause and effect, or the concepts of determinism, evolution, and so on. They supposed that just as scientific scholarship could establish the definitive text and succession of the documents they published in sophisticated and invaluable volume series; it could also determine the exact truth of history (Hobsbawm, 2013). History was, therefore, an extremely backward discipline. Its contributions were insignificant and occasional to the understanding of human society, past and present.

\section{b) Marxism or revisionism History}

From the end of the nineteenth century, scholars of historiography presented new approaches to historical narrative. A closer look takes the reader back to 1900, when Karl Lampretch expressed his challenge to Ranke's historians by coining the expression histoire événementielle, the narrative centered on events (Burke, 2011). The "history seen from above" started to receive the contribution of the subordinate categories in command, with privilege for the socioeconomic issue. From this fact, the proletariat that participated in the war effort in the factories, as well as the daily life of soldiers and citizens who participated in the conflicts, received the attention of researchers.

Thus, a transition period from linear factual history to structural history began, in which the presented categories enunciated their characteristics these presented points of tension between them. The narrative perspective received contributions from France, associated with the articulation of two historians, Lucien Febvre and Marc Bloch. Febvre and Bloch founded the journal Annales d'historie économique et sociale in 1929, and, famously, began to have new impulses after World War II (1939 - 1945) and, above all, with the death of Bloch in World War II in 1944. historian Eric Hobsbawm makes a personal revelation about Karl Marx's contributions:

It concerns the Marxist approach to history with which I am associated. Although the label is vague, I don't reject it. Without Karl Marx, I would not have developed any interest in history, which, as taught in the first half of the 1930s, was not an inspiring subject. Even if I felt that much of Marx's approach to the story needed to be thrown away, I would continue to consider, deeply but critically, what the Japanese call a Sensei (Hobsbawm, 2013).

The English researcher refers to the vague label, in bold in the previous quote, because of the facts that occurred around the publication of his writings. Far from the ideological conception that one might think about Marxist or revisionist historiography, the history states from the categorical material point of view, based mainly on economic aspects, provoked the ire of the

\footnotetext{
8 Marc Bloch, of French Jewish descent, was shot dead by the German Gestapo during the Nazi occupation of Vichy (France) in 1944.
}

Soviets. They did not translate any of their books into Russian. Even in France, Hobsbawm confided that he found it difficult to publish in Paris one of his works: "The Age of Extremes." The explanatory model shocked Parisians in the sense that there were a war tha lasted for 31 (thirty-one) years and that the economic and military punishments imposed by the Triple Entente on those defeated in World War I, catalyzed the socioeconomic transformations in those countries ${ }^{9}$. The defeated went through a cycle of recession, disenchantment with the liberal model, and the adherence to ultra-nationalist movements, as happened with National Socialism in Germany.

Additionally, Hobsbawm clarifies his perception of the transformation of the military profile over the thirtyone years of conflict. The "trench warfare" aimed to consume the surplus stocks of large industries. The economic model adopted by England throughout the nineteenth century led to the use of the concept of total war, where all efforts of nations focused on combat.

That all changed in 1914. World War I involved all the Great Powers, and indeed all the European states, except Spain, the Netherlands, the three Scandinavian countries, and Switzerland. What's more: troops from overseas were, sent, often for the first time, to fight and operate outside their regions. Canadians fought in France, Australians and New Zealanders forged national consciousness on an Aegean peninsula - "Gallipoli" became their national myth - and, most importantly, the United States rejected George Washington's warning of "European complications" and sent in their soldiers there, thus determining the shape of twentieth-century history. It is almost unnecessary to show that World War II was global. Virtually every independent state in the world got involved, whether they wanted to or not, although the republics of Latin America only participated more nominally. The colonies of the imperial powers had no choice. World War II was a world geography class. (HOBSBAWM, 1995)

Technological advances also demanded more specialized soldiers, and as a result, the need for new specialized training schools increased. We also observe similar developments in Brazil. After two intermittent periods of the adoption of Sergeant schools (1894 1897) and (1921 - 1933), specialist schools were created, such as the Specialized Instruction Center, now the Specialized Instruction School, in 1943, the War Material Instruction Center, current Logistics Sergeant School, in 1939 and the Sergeants of Arms School of in 1945.

According to the example previously illustrated about the Second World War (1939-1945), the economic importance of making logistics of war feasible was

\footnotetext{
9 The Triple Entente was a military alliance between the United Kingdom, France, and Russia. In practice, it consolidated the previous bilateral agreements: the Franco-Russian Alliance (1891), the Entente Cordiale between France and the United Kingdom (1904), and the Anglo-Russian Entente (1907) (Britannica, 2018)
} 
emphasized. The activities of the Brazilian Expeditionary Force (FEB) ${ }^{10}$ depended on the acquisition of the entire supply chain of the Armed Forces of the United States of America, from uniforms to aircraft. The Chief of Staff of the FEB, Colonel Lima Brayner, categorized the logistical situation of the "Pracinhas" before the allies and reported a moment of tension in the conversation between General Mascarenhas de Moraes and the Chief of the Peninsular Base Section (PBS) ${ }^{11}$ in Naples, Italy:

The Supreme board of provision was PBS, which exercised a true tyranny over the theater of operations, in terms of logistical support, its decisions were not appealable. His commander was a Lieutenant General, who was not a professor of cordiality. Only when Annapolis arrived did I begin to understand the extent of our disarmament. Few very few officers spoke English. And today, PBS men did not admit understanding in another language. The clothes and uniforms brought from Brazil washed aboard General Mann and in Agnano's parking lot, shrank immeasurably. The fabrics were, criminally, of poor quality, and the colors were not firm. Men of big complexion had an exotic, depressing and even ridiculous appearance. To partially correct that mismatch, all I saw was the inevitable appeal to PBS. And, with this, General Mascarenhas agreed. This inspiration came from the American liaison officers themselves, who, advised us to ask urgently for everything we needed after consulting their chiefs. The disappointments did not take long, however. PBS did not welcome our petition. We shouldn't have come. That was the cold truth. If we were, for example, like South Africans or Canadians, or New Zealanders, who brought everything from their country, including transport and maritime escort, the Americans would receive us with a number one smile. But there (the Brazilians, italics added) only had cannon fodder and the great loyalty, typical of Brazilians. Faced with a voluminous request from the Brazilian command, the American general did not hide his surprise and, without containing his irreverence, asked through his interpreter, in an ironic tone, and strictly speaking, it represented a censure: after all, what have you brought to fight? (Brayner, 1968).

According to the revisionist approach, it is possible to draw a parallel between the perception of readiness of the FEB and other armies at the start of the

\footnotetext{
${ }^{10}$ The creation of the Brazilian Expeditionary Force (FEB) took place after the Declaration of War in Decree 10,358, by the then President of the Brazilian Republic, Getúlio Dornelles Vargas, on August 31st, 1942, approaching the United States after the Japanese attack on Pearl Harbor on December 7, 1941. Ministerial Ordinance No. 4744, of August $9^{\text {th }}, 1943$, defined the structuring of the FEB and, therefore, it acted, finally, as the 5th North American Army in the Italian region of the Apennines between 1944 and 1945. After clashes with the German Nazi army and the German surrender to FEB troops on May 2, 1945, the Brazilian Expeditionary Force had its lightning demobilization on June $6^{\text {th }}, 1945$

${ }^{11}$ The Peninsular Base Section (PBS), a large echelon dedicated to the transport, supply, and maintenance of the V US Army and the VIII British Army, was responsible for Mediterranean Theater of Operations (Pereira and Faria, 2020). Colonel Lima Brayner pointed out that PBS, although it had it all, was responsible for replenishing the supply of troops deployed in the US and allied countries (Brayner, 1968).
}

Italian campaign in July and August 1944. The categories of troops that prepared from the beginning, with readiness and own transportation whereas the Brazilian military personnel, who received basic training in Rio de Janeiro and needed all the equipment from the Americans. By exploring the findings of the Chief of Staff of the FEB, it becomes clear that the country showed deficiency, regarding the economic and social point of view, in preparing the Brazilian soldier for a war in which logistics entered all stages of modern combat:

Supply and logistics would give a clear victory in World War $\mathrm{II}$, and at an almost marginal cost, except in human pain, to the winner. The United States, which had entered World War I at a later stage, entered World War II earlier, in 1941, after two years of rearmament, undertaken to provide England and then the Soviet Union with the means to fight against Nazi Germany. American Industry has overtaken its German and Japanese enemies, though only because of the American shipyards. On average, they launched three new Liberty cargo ships a day. Germany could not produce submarines as much as it lost them, even before they were defeated by introducing long-range aircraft and escort aircraft carriers in the Battle of the Atlantic. Supply and logistics, therefore, which ensured victory in the greatest and most fearsome of wars (Keegan, 1995).

When describing the phenomenon in categories, we can verify the possibility of comparison between them, such as, for example, the level of industrial development of each country involved in the war, the supply logistic chain, and the soldiers' mobilization processes. As a result, it is also verified the sources of transformational tension, that is, the point or points that allow the identification of small changes in the way of thinking and acting of the human being, the materialist conception of history added a new way of explaining the phenomenon:

As it happens, I continue to consider that Karl Marx's materialist conception of history is by far the best guide to history: the record of human society, or world civilization; of the changes taking place like this society; of revolutions and insurrections of one set of people against another, with the consequent kingdoms and states endowed with their various levels; of the different activities and occupations of men, whether to earn a living or in the various sciences and arts; and, in general, of all the transformations suffered by society due to its very nature (Hobsbawm, 2013).

On the other hand, criticisms of traditional historiography pointed to the limitations of attention to events as a form of scientific narrative. For Hobsbawm, history is the raw material for nationalist or ethnic, or fundamentalist ideologies. The past legitimates (Hobsbawn, 2013). However, the nation-building process involves myths, mixing historical facts and fiction. The emergence of manifestations of national particularities occurred under Romanticism in the 19th century (Kodama, 2013).

Paradoxically, the past remains the most efficient analytical tool for constant change, but in a new 
way. It becomes the discovery of history as a process of directional change, development, or evolution. Face of the overwhelming reality of transformation, even conservative thinking turns historicist. A kind of historicism, that is, the more or less sophisticated and complex extrapolation of past trends. It was the most popular and convenient method of forecasting (Hobsbawm, 2013). History as the "mainline of life," in which the phenomenon tends to repeat itself given some similar circumstances, represents the trap for those who intend to write and analyze the phenomenon solely based on facts, disregarding geographic and historical-cultural influences.

A particular example is reserved for the facts involving the military elite and the combats in the late nineteenth century, amid of traditional historiography. Despite taking Military History in school (Motta, 1998), the officers took long to realize that the use of supply routes to supply the troops in the vicinity of Arraial de Canudos, between 1896 and 1897, could not be done in the same way as the issue was dealt with in other regions of Brazil, which has continental dimensions. The supply system was carried out by contracting local suppliers, to whom they distributed insufficient quantities for the daily consumption of the troops. In addition, cattle, similarly to operations in the south, were escorted by pedestrians and were expected to be fed by pasture areas, a fact totally different from the "caatinga" in the Bahian wilderness semi-arid region.

On top of that, there was no specialized section for the execution of logistical support, which made inspection incipient. As an example, in August 1897, a reinforcement of 1000 (one thousand) men and 100 (one hundred) oxen to feed the troop was attacked by followers of Antônio Conselheiro, reducing to 11 (eleven) the amount of the herd that was destined to feed more than 4000 men (Mc Cann, 2009). To make the setback even worse, the soldiers were being affected by an outbreak of smallpox that decimated the entire troop and, in this scenario, revealed be chaotic; despite the large financial resources that were allocated to the fourth expedition, the result was not effective on the front lines.

The romanticized approach of the leaders and the battles at the Escola Militar, and the euphoric spirit ${ }^{12}$ of the soldiers who were followers of Floriano Peixoto

\footnotetext{
${ }^{12}$ The impetuosity could explain the improvidence in the case of the Regiment commanded by Major Febrônio de Brito, which the theater of operations or even the Moreira César column is not known. This atypical Battalion, separated from the hierarchy by a specific political situation, left the Federal Capital for Canudos in days, surrounded by a Florianist "romantic aura" of "defense of the Republic" at any price; its negligence was such that, as seen, all the logistics related to water, in a troop that would move through the hinterland, boils down to an artesian pump, transported into the hinterland without anything that would allow at least the penetration of the probe (Trevisan, 2011).
}

contributed to the augment of the troops who intended to "impose a punishment" to the followers of Conselheiro. But, after the failures of the first three expeditions, especially at the occasion of Colonel Moreira César being killed in combat, the Minister of War Carlos Machado de Bitencourt had difficulties in gathering a force of approximately 14000 (fourteen thousand) men to the fourth expedition, including military police from different states of the federation. The "justice" that the first three expeditions intended to give Canudos, equated to an "energetic delegate plan," gave way to fear: the number of "sick documents" among the summoned officers increased considerably, as well as desertion and abandonment of the injured in the campaign, resulting in investigations and punishments after the conflict (Trevisan, 2011)

Therefore, the historical narrative is not just about common sense: the ability to discern general trends does not imply predicting their precise outcome in complex and, in many respects, unknown cultural circumstances. According to Hobsbawm, in positivist terms, order follows progress, but the analysis of one tells us little about the desirable pattern of the other (Hobsbawm, 2013). Master History suggested traditional historians should anticipate data and results as if it were a mathematical equation, referring the analyst to teleology, that is, the direct prediction of results through facts and consequences of the past.

In short, the revisionist critique of traditional historiography revolves around the superficiality with which historical phenomena are treated because there is no delimited boundary between fact and fiction. The ability to distinguish between the two is critical for historians today.

These and many other attempts to replace history with myth and invention are not just bad intellectual jokes; after all, they can determine what goes into schoolbooks, as the Japanese authorities knew when they insisted on an aseptic version of the Japanese war against China in Japan's classrooms. Myth and invention are essential to the politics of identity whereby groups of people, defining themselves today by ethnicity, religion, or national borders past the present, try to find some certainty in an uncertain world and unstable saying: we are different and better than others. They are the ones that worry us in universities. Why the people who were those myths and intentions are cultured: professors, journalists, producers of radio and television. Make no mistake about it. History is not ancestral memory or collective tradition (Hobsbawm, 2013).

Such examples from Marxist and new history historians provide an overview of the structures and tensions between categories established by historiographical research methods. In this way, revisionism presented these contributions as a way of constructing a scientific narrative. However, this contribution did not solve many of the problems of historical investigation, which generated a new 
movement in the late 1970s in France and, in the late 1980s, in Brazil.

\section{c) Contributions for the New Military History}

But in this universe that expands and fragments with a growing need for guidance, what is the so-called New History? How young is it? Is it a temporary fad or a long-term trend? Will it - or should it - replace traditional and Marxist history? Or can rivals peacefully coexist?

The expression coined as "new history" was widespread in France. "La nouvelle histoire" is the title of a collection of essays edited by the renowned French medievalist Jacques Le Goff. He assisted in the editing of a massive threevolume collection of essays on new problems, new approaches, and new objects (Burke, 2011).

Narrative models centered on establishing the facts and with a socioeconomic bias received new contributions, to expand the range of interest of history researchers. Criticism of the thought that history could only be studied after 100 (one hundred) years after the fact, or after the object of research had all its members dead, became unfounded after new studies on World War II World raised political-military collaboration in Vichy France. $^{13}$ The refusal to recognize the responsibility of the French State in 1992, 47 (fortyseven years) after the end of the War and finally, 48 years after its release in 1944, is the indicative of the difficulty of that Republic in gaining access to the obstructed past, that is, a past that has not ended (Cardoso, 2012).

Locating the place where the "emergence" of history testimony takes place is to carry out the movement of a temporal search. The reported observation ignores the scientist's cold objectivity, which counts and explains. It is the temporal dimension created by the awareness of a non-geographic place, but temporal from the tension between times, as if it were "a past that does not pass" or a conscious "silence" about a certain period, produced by the collective shame in discourse about the theme, with an air of taboo. The defeat of France in 1940 and the creation of the State of Vichy started French collaboration with the victorious enemy. The acknowledgment of this episode met strong institutional resistance and even among historians (Cardoso, 2012). Together with the emergence of the study focused on testimonies, the History of the Present Time made it possible for historians to deepen their research in parallel with human experience. Pieter Lagrou, one of the researchers at the Institute of History of the Present Time (IHTP) since 1998, makes the following definition:

\footnotetext{
${ }^{13}$ On July $14^{\text {th }}, 1992$, the French President of the Republic refused to respond to an appeal by intellectuals calling on him to officially recognize that the French state of Vichy is responsible for persecution and crimes against Jews in France.
}

How is the present tense defined, if not as a continuum between the periods studied and the moment of writing? (...) The characteristic of the history of the present time would consist in what can be called the temporal unity of the subject and the object, of the one who studies and what he studies. The historian is contemporary with the events differently from that of physical cohabitation with witnesses. The period studied is not closed: not to this element of alienation, of alterity, which is typical of studying more distant periods. The cognitive painting that would prevent mental identification with its object of analysis has not yet occurred (Lagrou, 2007).

The perception of the risk of disappearance of the historical experience caused by prohibitions, by the dilution of meanings, and, with time, by silence, can induce the need to resort to other methodologies, such as oral history. ${ }^{14}$ Oral history can also fill gaps in the environment in which the main decisions were taken, such as, for example, the FEB memoir books. ${ }^{15}$ And, more recently, episodes such as the Federal Military Intervention in the State of Rio de Janeiro, Brazil, in which the Brazilian Army participated in the complete management of public security in the region between February 16 $6^{\text {th }}, 2018$, and January $1^{\text {st }}, 2019$ (Brasil, 2018). Oral history interviews are taken as sources for understanding the past, along with written documents, images, and other types of records. They are characterized by being produced from a stimulus. The researcher looks for the interviewee and ask them questions, usually after the fact or situation under investigated has been consummated. Furthermore, it is

\footnotetext{
${ }^{14}$ Oral history is a research methodology that consists of conducting recorded interviews with people who can testify about events, situations, institutions, and ways of life, or other aspects of contemporary history. From the 1990s onwards, the movement around oral history grew a lot in Brazil. In 1994, the Brazilian created the Association of Oral History. The oral history methodology comprises a whole set of activities before and after recording the testimonies. It requires research and data collection for the preparation of interview scripts. When the work is carried out by an institution that aims to build a collection of testimonies open to the public, it is necessary to take care of the duplication of recordings, conservation, and treatment of the recorded material (CPDOC, no data).

${ }^{15}$ The collective memory and its legacy, entitled by Jacques Le Goff as a "monument," has the characteristics of being linked to the power of perpetuation, voluntarily or involuntarily, of historical societies and sending it back to testimonies that are written testimonies in only a small portion (Le Goff, 2013). The works written by military personnel from the different levels of the FEB have this characteristic, narrating the testimonies and the presence of some documents necessary to compose the theme. However, the critical reflection between these works is the responsibility of the historian and their documentary sources, which go beyond written documents (Le Goff, 2013). As examples, we can cite, among other works, the following books: A FEB by its commander (1947) and "Memórias" (Memories), by João Baptista Mascarenhas de Moraes (2014); The Truth About FEB, by Floriano de Lima Brayner (1968); Brazil in the Second Great War, by Manoel Thomaz Castello Branco (1960); and Statement by Reserve Officials on the FEB (1949). Francisco Ruas Santos also presented works on the subject. However, we highlight the applied research on the Sources for the History of FEB (1958), an essay which makes a collection of information about the episodes in which the FEB participated and the authors of the works that deal with the subject.
} 
part of a whole set of biographical documents, as well as memoirs and autobiographies, which allow us to understand how individuals have experienced and how they interpret events, situations and ways of life of a group or society in general. It makes the study of history more concrete and closer, facilitating the apprehension of the past by future generations and the understanding of the experiences lived by others (CPDOC, no data).

The priority given to testimonies lived or collected directly did not prevent ancient historians from criticizing these testimonies. Thus, Thucydides, a Greek philosopher, who considered history as an investigation, says about the Peloponnesian war $\left(5^{\text {th }}\right.$ century $\mathrm{BC}$ or 431-404 BC):

As for the narration of the war events, I thought I should not write them relying on information from anyone, nor my impressions; I speak only by eyewitnesses or after a review as accurate and complete as possible. Not without difficulty; the testimonies in each event differ according to the sympathies and memory of each one. My story will have less charm than the myth. Still if you want to clarify the history of the past and recognize the similarities and analogies of the human condition in the future, it is enough for me to find. Its story is a definitive achievement and not an ostentatious work for an audience of the moment (Tucídides, I, 1987).

The investigative process enunciated by Thucydides involved a variety of methods for describing facts concerning politics and war. Political history, as well as the role played by military commanders, gained a new theoretical-methodological impulse with the "nouvelle historie." Although biographical texts remained outside the attention of historians for decades, the search for information on political leaders and personalities helped to open up the range of thematic possibilities. ${ }^{16}$

In this way, both the politics and the actions of the military and civilians who participated in the war effort received new focuses beyond Marx's facts and socioeconomic perspective. An example of this new approach is found in the historiographical vision identified by Francisco Doratioto in "Maldita Guerra: a new history of the Paraguayan War," which helped to fill gaps left by traditional historiographic works on the Paraguay War, or the Triple Alliance War (1864- 1870), with a focus on the role of military commanders in the conflict and, above all, in contrast to the Marxist narratives of Júlio José Chiavenatto. ${ }^{17}$ And León

\footnotetext{
${ }^{16}$ The heating up of the publishing market for specialized biographies on military leaders, such as Napoleon Bonaparte (1769-1821) and other commanders, contributed to the fact that biography, as well as political history, entered the scene of history researchers. For more details, see DOSSE, François, The biographical challenge (2015).

${ }^{17}$ Genocídio Americano: a Guerra do Paraguai (1979)
}

Pomer $^{18}$, centered on the economic motivation for the war in the La Plata region.

In this aspect, it is worth highlighting the use, by the new history, of interdisciplinarity to help in the narrative. Contacts with sociology, geography, political science, mathematics, statistics, linguistics, psychology and anthropology also bore fruit, resulting in the development of works on sociability, culture, and even on discourse analysis (Rémond, 2003). Like political history, it is impossible for military history to practice isolation: crossroads science, multidisciplinarity works for military history like the air works for our breathing (Rémond, 2003). This is because the military theme takes on different directions based on the view that the military does not correspond to a caste but an extension of the society that created it (Weigley, 1982).

Additionally, interdisciplinarity contributes to the perception of new values in military training. Hobsbawm argues that as it is now, technology in its broadest sense belongs to the flexible sector, whereas social organization and ideology or value system belongs to the inflexible sector (Hobsbawm, 2013). Samuel Huntington reinforces the thesis of the immutability of military values:

Today soldiers are also French and Americans, Methodists and Catholics, living liberals, and Jewish and anti-Semitic reactionaries. Any statement given by a military man may not reflect their attitudes as military that regulates but may, instead, derive from social, economic, political, or religious origins, irrelevant to their military status, the military mentality is therefore defined abstractly as an ideal type The way of life, in terms of what beliefs of real men and groups can be analyzed. As long as there is no inherent change in the military function, there will be no change in the context of professional ethics. Improved changes in military techniques, such as developments in weapons technology or greater importance in the economics of military business, in no way alter the character of military ethics; just as the discovery of penicillin has provoked no changes in medical ethics (Huntington, 1996).

However, in the absence of comparative historical studies, the question of changes in military values must always remain open. Alfred Stepan, for example, formulated the idea of the "new professionalism," where this process did not make the military limited to objective civilian control, as occurred in the United States of America (USA) ${ }^{19}$. In this sense, Eliézer Rizzo de Oliveira highlights the use of the Armed Forces within the homeland "as a last resource to maintain the supremacy of the legitimately established

\footnotetext{
${ }^{18}$ Guerra del Paraguay: iGran negocio! (1968).

${ }^{19}$ In the objective sense, civilian control is the maximization of military professionalism. More precisely, it is that distribution of political power between military and civilian groups, a distribution that leads to the emergence of professional attitudes and behavior among the officialdom. Objective civilian control reaches its peak by "militarizing" the military, and the antithesis of this control is the participation of the military in politics. (Huntington, 1996).
} 
order" (Oliveira, 1994). Thus, it is possible to conclude that the works produced by Oliveira and his study group at the University of Campinas emphasized the need to return to the study of the military institution, paying attention to its "internal," "structural," or "organizational" aspects (Castro, Isecksohn; Kraay, 2004).

In this scope, Thomas Bruneau, while observing the political-military world, found that cultural aspects interfere in the perception of democratic values within the armed forces (Bruneau \& Matei, 2013). This parallel alters the immutable panorama of objective civil control, outlined by Samuel Huntington (1996), contextualized at the national level.

An example of this change is the gradual shift that started in the 1990s, from an institution focused on total war to a structure that also focus on non-war actions or combat with limited use of force. For example; there are the designation of the Armed Forces for the peace missions of the United Nations. Other examples are the interagency operations in support of government bodies, and law and order operations. And all changes are in the evolutionary trajectory of legislation, based on chronological grounds in Article 142 of the Federal Constitution of 1988 (Brasil, 1988).

Therefore, military history writing assumes the complexity inherent to the three historiographic currents - Traditional, Revisionist, and New History - condensing knowledge and practices of the historian's job. In summary, the table below illustrates some specific changes that took place from the $19^{\text {th }}$ century onwards:

Tab. 2: Perspectives of new history historiography according to Burke (2011), and Hobsbawm (2013). Adaptation made by the author.

\begin{tabular}{|c|c|}
\hline Eric Hobsbawm's Contributions & Peter Burke's Contributions \\
\hline $\begin{array}{l}\text { Political and religious history had visibly } \\
\text { declined while national histories seemed } \\
\text { antiquated. In return there was a } \\
\text { remarkable turn in socio-economic history. }\end{array}$ & $\begin{array}{l}\text { The new History began to take an interest in virtually all human activity. } \\
\text { Everything has a history, everything has a past that can be reconstructed } \\
\text { in principle and related to the rest of the past. Hence the expression } \\
\text { "total" history so dear to Annales historians }\end{array}$ \\
\hline $\begin{array}{l}\text { It was no longer common, or really easy, to } \\
\text { use ideas as an explanation of history. }\end{array}$ & The new history is more focused on analyzing structures. \\
\hline $\begin{array}{l}\text { Current explanations were now given in } \\
\text { terms of social forces, although this } \\
\text { acutely raised the question of the } \\
\text { relationship between the explanation of } \\
\text { historical events and the explanation of } \\
\text { individual actions. }\end{array}$ & $\begin{array}{l}\text { Several new historians are concerned with "history from below"; and, in } \\
\text { other words, with the opinions of ordinary people and their experience of } \\
\text { social change. Historians have also shifted their attention from great } \\
\text { books to the history of collective mentalities or the history of collective } \\
\text { discourses or languages. }\end{array}$ \\
\hline \multirow{2}{*}{$\begin{array}{l}\text { It was difficult to talk about progress or } \\
\text { even significant development of events in a } \\
\text { certain direction. }\end{array}$} & $\begin{array}{l}\text { Oral history and the use of specialized statistics, in this case, contribute } \\
\text { to offering new perspectives on what is reported in institutional reports. }\end{array}$ \\
\hline & $\begin{array}{l}\text { The new history will draw on all those discoveries being made about } \\
\text { humanity by anthropologists, economists, psychologists and } \\
\text { sociologists. The movement for change arose out of a fused perception } \\
\text { of the inadequacy of the traditional paradigm. Likewise, it is not } \\
\text { unreasonable to speak of the crisis of the traditional paradigm of the } \\
\text { writing of history. However, the new paradigm also has its problems: } \\
\text { definition problems, font problems, method problems, explanation } \\
\text { problems. }\end{array}$ \\
\hline
\end{tabular}

Thus, the historiographic contributions allow the young researcher a possibility to use new theories and methods to write history. However, it is also important for the historian to verify the limitations of each aspect so that he does not to incur an anachronism of the narrative. As can be seen, each current had contributions in periods, with traditional historiography being at the forefront until the 1930s, Marxist revisionism until the 1970s, and "nouvelle histoire" from the 1980s onwards.

Due to the aspects presented, the main objective is to show that historiography has been moving in a specific direction throughout several generations, culminating in a new history, basically being an existing academic theory projected in the past that can help to accredit new researchers to a reputation for launching a new fad or for formulating something that no one has said before (Hobsbawm, 2013). Thus, history, as a school subject, is currently more fragmented than ever: historians can speak the language of economists, of philosophers, of anthropologists, but these groups find it increasingly difficult to talk to each other. The proliferation of historical research and interdisciplinarity has its advantages: it contributes to human knowledge and encourages stricter methods, and professional standards (Burke, 2011).

\section{ili. Conclusion}

The objective of this article was to provide an overview of the historiographic contributions from Ranke's generation to the present day. Along the pages, 
we observed three approaches to the military history writing. Although the creation of the Military History group work is recent, in 2016 in Rio de Janeiro, it is important to highlight the thematic relevance and possible interpretations by old and new researchers. Since the end of the 1980s, the analyses started to have a greater temporal scope. Today, the history professional can approach the present and the respective dialogue with the past. Through events, the historian analyzes the structures and closely observes the changes between the time studied and the present through the sources and research methods available.

Professional analysis, added to the interdisciplinary perspective, is beyond documentary confirmation of facts and dates, it assumes a multifocal aspect, showing military history seen from all sides. The challenge for the military historian is to show how he forms part of history, relating everyday life to "great events." New studies on the military theme are presented every year, showing that it is very far from ending.

Furthermore, the depth of analyses is increasing. However, it is necessary to emphasize the historicity regime in which history scholars are involved. Historians and other analysts of the process and development of the natural sciences know that progress is far from linear, but its existence cannot be disputed. Twentieth-century literature is no better than seventeenth-century literature (Hobsbawm, 2013). These are stories told by men of their time. And there are still many works of traditional historiography that stood out for their depth of analysis that still work as a paradigm for future perspectives. If we ever read works by older historians, it is either because they provide us with some permanent corpus of historical raw material, an interpretation of an unsurpassed edition of medieval chronicles, For example, or because they are casually interested in a topic that has not cited later works but which, or for another reason, arouse our interest again: in other words, we concluded that all the works are of certain importance for the investigation.

The challenge is to break the paradigm of the commonsense view of history, separating the legend and reaffirming the commitment to what is real. For this, it is necessary to dialogue with the innovations of the three periods, in which each one has peculiar observations, such as the additional resources to the printed documents, the location of tensions between the structures and the historical approach, increasingly free from judgments of value, these are peculiar to social communication actions, not to History. The "novel" and the linearity attributed to the past, without relevant updates to the investigation of history, can induce the reader, specialized or not, to memorization and lack of critical reflection of facts and leaders, without problematizing the other sources that are involved in that historic process. This happens due to the fact that modern social science, politics, and planning have adopted the model of scientism and technical manipulation that systematically neglected the human and, above all, historical experience.

Therefore, it is necessary for the investigator to read the documents between the lines. There is nothing wrong with trying to analyze other aspects than the speech, as long as the historian's point of view reflects the fundamental commitment to the truth established in his sources. And this is the first barrier that restricts innovation, highly sought by the new generation of historians.

Concluding the main idea, the restriction to high-politics, leaders and facts is not impeditive to military historians. The contributions of History to other scientific disciplines transport the researcher to the relationships that are part of everyday life, in a contextualized way with the time and the region to be studied. For that reason, the challenge for researchers is the perception of some contributions to the writing of a scientific work according to the generation to which they belong, respecting the historicity of the period they propose to research, establishing the past-present connection, pointing out the transformations on the military theme through the ages.

\section{References Références Referencias}

1. ANPUH/RJ (2021). Military History Working Group (GT) - Rio de Janeiro Section. Niterói: Anpuh/RJ. Retrieved from https://www.facebook.com/groups/ 151903671615320.

2. BARTELMEBS, R. C. (2012) Reviewing the Structures of Thomas Kuhn's Scientific Revolutions. In: Revista Ensaio, volume 14, no 3 p. 351 - 358. Belo Horizonte: UFMG. Retrieved from https://www. scielo.br/pdf/epec/v14n3/1983-2117-epec-14-0300351.pdf.

3. BRASIL. (1988) Presidency of the Republic. Constitution of the Federative Republic of Brazil. Brasilia: Deputy Chief of Legal Affairs, 1988. Retrieved from http://www.planalto.gov.br/ccivil_03/ constituicao/constituicao.htm.

4. BRASIL. Presidency of the Republic. Decreto n. ${ }^{\circ} 9$ 288, de 16 de fevereiro de 2018. Brasília: Deputy Chief of Legal Affairs, 2018. Retrieved from http:// www.planalto.gov.br/ccivil_03/_ato2015-2018/2018/

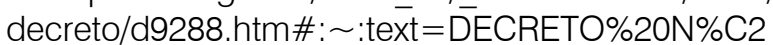
\%BA\%209.288\%2C\%20DE\%2016,grave\%20compro metimento\%20da\%20ordem\%20p\%C3\%BAblica.\&t ext $=$ O\%20PRESIDENTE\%20DA\%20REP\%C3\%9AB LICA\%20\%2C\%20no,que\%20lhe\%20confere\%200\% 20art

5. BRITANNICA. (2018) Triple Entente. Retrieved from https://global.britannica.com/topic/Triple-Entente.

6. BRUNEAU, T. C.; MATEI F. C. (2013) The Routledge handbook of civil-military relations. London: Routlege Taylor \& Francis Group. 
7. ODÁLIA, N (Translation) (1948). BURKE, P. (Author). The Annales school (1929-1989): the french revolution of historiography. São Paulo: Editora Unesp.

8. LOPES, M (Translation) (2011). BURKE, P. (Author). History writing: new perspectives. São Paulo: Editora Unesp.

9. CAFÉ HISTÓRIA(2017). Francisco José Calazans Falcon: a tribute to. Retrieved from https://www. cafehistoria.com.br/homenagem-falcon/.

10. CARDOSO, C. F; VAINFAS, R. (2012). New domains of history. Rio de Janeiro: Elsevier.

11. CARDOSO, I. (2012). The past that does not pass: historical places of testimonies. In: VARELLA, F; MOLLO, H. M; PEREIRA, M. H. F; MATA, S. Present tense \& past uses. Rio de Janeiro: Editora FGV.

12. CASTRO. C; ISECKSOHN, V; KRAAY, H. (2004). New Brazilian Military History. Rio de Janeiro: FGV Editora.

13. CPDOC. (no data). What is oral history? Rio de Janeiro: FGV. Retrieved from https://cpdoc.fgv.br/ acervo/historiaoral.

14. FUNARI, P. P (2020). Greece and Rome . 6 ed. São Paulo, Contexto.

15. PAOLI, M. C (Translation) (1995). HOBSBAWN, E. (Author). Age of extremes: the brief 20th century (1914 - 1991). São Paulo: Companhia das Letras.

16. MOREIRA, C. K (Translation) (2013). HOBSBAWN, E. (Author). About History. São Paulo: Companhia das Letras.

17. DANTAS, L (Translation) (1996). HUNTINGTON, S. P. (Author). The Soldier and the State: Theory and Politics of Civil-Military Relations. Rio de Janeiro: Biblioteca do Exército.

18. MC CANN, Frank D (2009). Homeland Soldiers: History of the Brazilian Army (1889 - 1937). Rio de Janeiro: Biblioteca do Exército.

19. SOARES, P. M. S (Translation) (1995). KEEGAN, J. (Author). A history of war. São Paulo: Companhia das Letras.

20. KODAMA, K (2013). How do you build a nation? In: História do Brasil II, volume 2, p. 53 - 84. Rio de Janeiro: Fundação CECIERJ.

21. KUHN, T S (1997). The Structure of Scientific Revolutions. 5. ed. São Paulo: Editora Perspectiva S.A.

22. LAGROU, $P$ (2007). About the actuality of the History of the Present Time. In: PÔRTO JÚNIOR, G. (org). History of the Present Time. Bauru: Edusc.

23. LEITÃO, B; FERREIRA, I; BORGES, S (Translation) (2013). LE GOFF, J. (Author). History and memory, 7 ed. Campinas: Editora Unicamp.

24. MOTTA, J (1998). Brazilian Army Officer Training: Military academy curricula and regimes (18101944). Rio de Janeiro: Biblioteca do Exército.
25. OLIVEIRA, E. R (1994). From Geisel to Collor: Armed Forces, transition and democracy. Campinas: Papirus.

26. PEREIRA, F. S; FARIA, D. P (2020). The profile of the quartermaster of the Brazilian Army (1940-1950). In: Brazilian Journal of Development, volume 6, n 9, p. 67345-67365. Curitiba: Brazilian Journals. Retrieved from https://www.brazilianjournals.com/ index.php/BRJD/article/view/16451.

27. PORTUGAL (1940). The only seven documents from 1500, kept in Lisbon, referring to Pedro Álvares Cabral's voyage. Lisboa: Agência geral das colônias.

28. RÉMOND, R (2003).For a Political History, $2^{a}$ ed. Rio de Janeiro: Editora FGV.

29. RICOEUR, P (1996). Between mémoire et histoire. Projet. Paris: $n^{\circ} 248$.

30. RODRIGUES, J. H (1982). Conciliation and reform in Brazil: a historical-cultural challenge, $2^{a}$ ed. Rio de Janeiro: Nova Fronteira.

31. TODOROV, T (1995). Les abus de la mémoire. Paris: Arléa.

32. TREVISAN, L. N (2011). Patriotic Obsessions: Origins and Projects of Two Schools of Political Thought in the Brazilian Army. Rio de Janeiro: Biblioteca do Exército.

33. TUCÍDIDES (1987). History of the Peloponnesian War. Brasília: Editora Universidade de Brasília.

34. VELHO, O. A (Translation) (1982); WEIGLEY, R. F (Author). New Dimensions of Military History, 1st volume. Rio de Janeiro: Biblioteca do Exército. 